\title{
Community-Based Observations of Marine Mammal Occurrences in Groswater Bay, Labrador
}

\author{
Keith. G. Chaulk ${ }^{1}$, Daniel Michelin ${ }^{2}$, Melva Williams ${ }^{2}$, and Tony Wolfrey ${ }^{2}$ \\ ${ }^{1}$ Labrador Institute, Department of Biology, Memorial University of Newfoundland, P.O. Box 382 Station C, Goose Bay, \\ Labrador A0P1C0 Canada; e-mail: keith.chaulk@mun.ca \\ ${ }^{2}$ General Delivery, Rigolet, Labrador A0P 1P0 Canada
}

Chaulk, Keith G., Daniel Michelin, Melva Williams, and Tony Wolfrey. 2013. Community-based observations of marine mammal occurrences in Groswater Bay, Labrador. Canadian Field-Naturalist 127(1): 31-37.

Experienced observers from the community of Rigolet, Newfoundland and Labrador, recorded marine mammal observations at Rigolet on the coast of Labrador from July to September 2012. During this study, a total of nine species of marine mammals were documented. A daily average of 2.6 (range 1-5) marine mammal species were observed, with Harp Seals (Pagophilus groenlandicus) and Common Minke Whales (Balaenoptera acutorostrata) being the most common. The area is thought to be regionally important for Ringed Seal (Pusa hispida) whelping; however, Ringed Seals were not observed in large numbers. Beluga Whales (Delphinapterus leucas) were also reported anecdotally, but were less common than the other species, with the possible exception of the Harbour Porpoise (Phocoena phocoena). Labrador is experiencing significant industrial growth related to hydroelectric development and offshore oil and gas exploration. These data should aid environmental assessment and environmental effects monitoring and assist researchers in understanding regional marine mammal ecology, including species diversity, seasonal occurrence, and relative abundance.

Key Words: seal, whale, Harp Seal, Pagophilus groenlandicus, Common Minke Whale, Balaenoptera acutorostrata, Ringed Seal, Pusa hispida, Beluga Whale, Delphinapterus leucas, Harbour Porpoise, Phocoena phocoena, marine mammal, biodiversity, Inuit, Groswater Bay, Lake Melville, Rigolet, Labrador.

Labrador forms the northeast coast of mainland Canada. This coastline is complex, with many islands, islets, fiords, bays, and rivers (Lopoukhine et al. 1978). Even though Labrador represents a sizable proportion of the overall Canadian coastline, very few studies of marine mammal biodiversity and seasonal abundance have been reported for the region. Various researchers have investigated individual seal species in the region, particularly in relation to diet, movement patterns, or contaminants (e.g., Beck et al. 1993; Stenson and Sjare 1997; Oftedal et al. 1996; Kuzyk et al. 2005; Andersen et al. 2009). However, there is much less information on the overall seasonal diversity and occurrence of marine mammals in the region, and much of what is available is dated (e.g., Sergeant and Fisher 1957) or is concerned with historical hunting patterns (e.g., Arkham 1984). Here, we present a community-based survey of seasonal occurrence of marine mammals conducted by Inuit in Rigolet, Labrador.

The region is classified as coastal barrens (Lopoukhine et al. 1978). It is considered to have a high-boreal ecoclimate (Meades 1990*) and a low arctic oceanographic regime (Nettleship and Evans 1985). The community of Rigolet is at the eastern end of the "Narrows," which is an important marine corridor between Lake Melville and the Labrador Sea (Atlantic Ocean) (Figure 1). The Narrows acts as a pathway allowing the nutrient-rich fresh waters of Lake Melville (a tidal water body) to exchange with the cold, saline waters of the Labrador Sea. The Narrows is also a regionally important shipping lane for the transport of fuel, cargo, and passengers, although very little information exists with respect to the overall amount of vessel traffic. The Narrows are also thought to be an important movement corridor for several locally important species, including Atlantic Salmon (Salmo salar) and the Ringed Seal (Pusa hispida). Finally, the area is also thought to provide important habitat for molting Surf Scoters (Melanitta perspicillata) (Rao et al. 2009*).

For many generations, local Inuit have observed that this area is highly productive and important for many species of fish, seabirds, waterfowl, and marine mammals, especially during ice-free periods. It is generally assumed that fresh water and organic materials from Lake Melville mix with the salt water of the Labrador Current to create a unique ecological setting that supports regionally high biodiversity and biomass. However, very few studies have investigated the ecosystem immediately surrounding Rigolet, or indeed the larger region of Lake Melville and Groswater Bay. In 2012, the Rigolet Inuit Community Government initiated an observation program to document marine mammal biodiversity and relative abundance during the summer and fall periods. The data could inform regional environmental assessment and ecological monitoring related to industrial activities such as marine shipping, hydroelectric development, and offshore oil exploration.

\section{Methods}

For the duration of the study, the field team consisted of two experienced local observers. Both were 


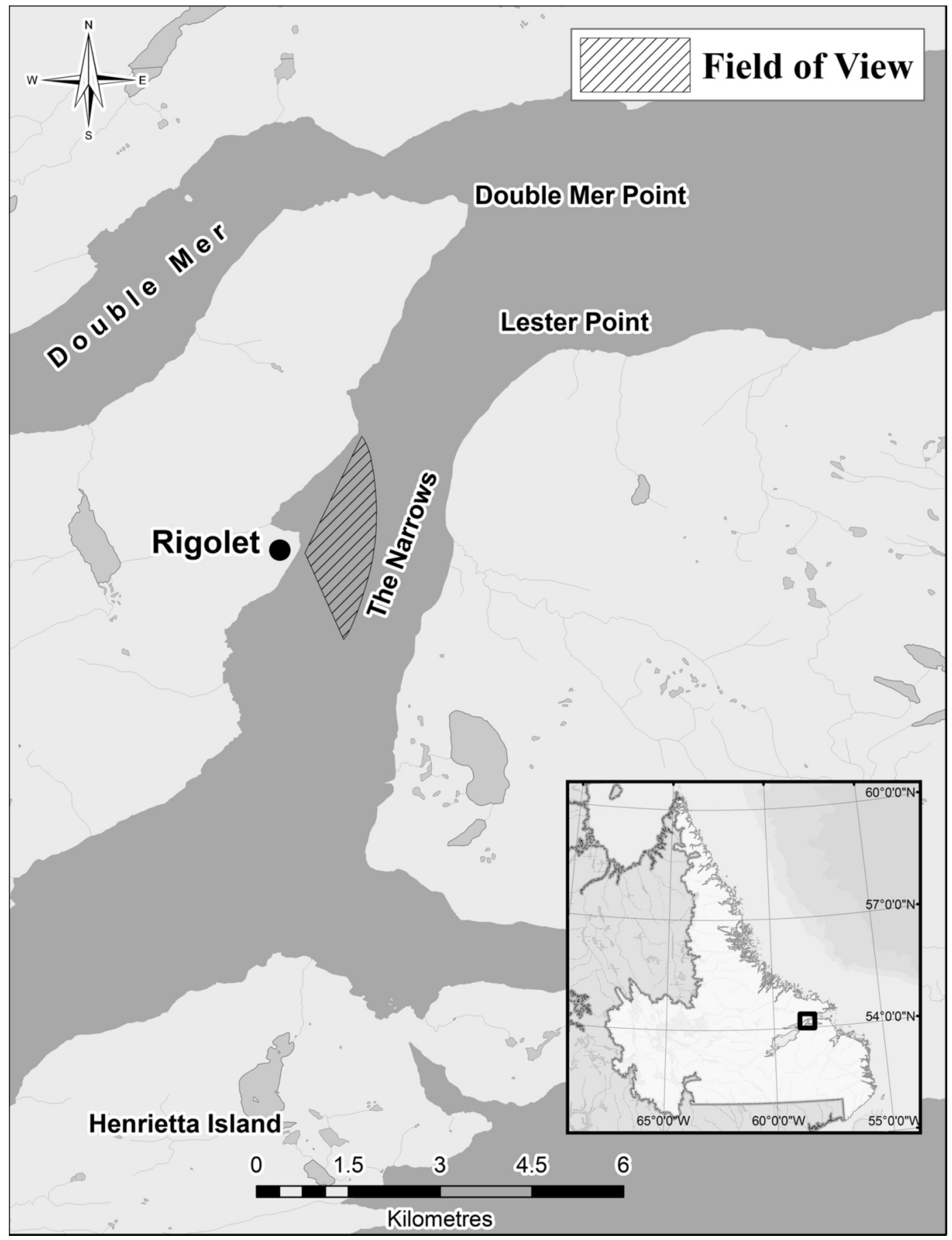

FIGURE 1. Study area, including the approximate location of the observation post and the approximate field of view (hatched area). Inset map shows the location of the study area within Labrador. 
local Inuit hunters with significant knowledge of marine mammal identification accumulated through a lifetime of land use and harvesting. In addition to this, the observers received supplemental training in the identification of marine mammals and marine mammal behaviour. This included watching videos of various types of behaviour classes (feeding, jumping, spying, etc.) and reviewing guidebooks on various types of marine mammals and their identifying marks. Training was also provided in observation and data recording methods, including the use of field sheets and computer software for data entry. Several categories of behaviour were included on the data sheets, including feeding, jumping, and spying, and these were assigned to each observation as appropriate.

An observation post (NAD 83: $54.180397^{\circ} \mathrm{N}$, $58.42513^{\circ} \mathrm{W}$ ) was established on the community waterfront at a height of approximately $3 \mathrm{~m}$ above sea level. Local landmarks were used to establish the field of view, which was estimated to be approximately 200 ha in area (Figure 1). Sightings within this area were recorded, but observations outside of the viewing area were not. The location of individual observations was not mapped. Initial sightings were made by eye. When possible, species identification was confirmed using $8 \times 42$ roof prism binoculars.

Daily observations were conducted between 0900 and 1540 Atlantic Daylight Time inclusive, for a normal program of 6 observation periods of 10 minutes each per day. These were conducted on the hour in the morning $(0900,1000$, and 1100) and on the half hour in the afternoon $(1330,1430$, and 1530). This program was implemented at least four days per week, from Monday to Friday, for the duration of the study. The study was conducted from 11 July 2012 to 28 September 2012, representing 303 observation periods of 10 minutes each (or 50.5 observation hours) over 52 observation days.

Observations outside of the field of view (see Figure 1) or the predetermined observation periods are referred to in this report as anecdotal observations and were not included in the analyses. If a species was observed one or more times during any given observation period, it was assigned a "1"; if it was not observed, it was assigned a " 0 ".

No effort was made to correct counts based on repeat observations. However, we did post-process the data for presence and absence and subsequently used this information to calculate a daily observation probability. For example, a typical day would have 6 observation periods of 10 minutes each. If a species was observed during only one observation period on a given day, the daily observation probability was $1 / 6(0.16667)$ (if there were fewer than 6 daily observation periods, the denominator was changed as appropriate). For the purposes of reporting, groups of marine mammals are referred to as pods throughout the report. Minitab (version 16) was used for data analyses.

\section{Results}

For the period July-September 2012, the automated weather station in the nearby community of Cartwright reported a three-month average temperature of $13.9^{\circ} \mathrm{C}$ and an average precipitation of $105.5 \mathrm{~mm}$. For the same three-month period, the 1971-2000 Canadian Climate Normals for Cartwright report an average temperature of $10.8^{\circ} \mathrm{C}$ and an average precipitation of $92.8 \mathrm{~mm}$ (Environment Canada Online*). These comparisons suggest that July to September, 2012 was slightly warmer and wetter than average for this section of the Labrador coast. Visibility was generally good throughout the study, even on overcast and rainy days. The study team recorded only one 10-minute observation period as "too foggy to see". In fact, days with high winds were the most problematic, as waves and/or whitecaps made it more difficult to spot marine mammals breaching the water. However, due to strong tides, wave heights above $1 \mathrm{~m}$ are less common in the study area than in Groswater Bay or Lake Melville.

In total, eight species were recorded over the course of 303 observation periods conducted over 52 observation days. The team counted a total of 1841 marine mammals (Table 1). Of these, 1015 (55\%) were seals and $826(45 \%)$ were whales. Harp Seals (Pagophilus groenlandicus) had the highest overall counts (Table 1) and were observed in relatively large pods, known locally as "sculls" (mean 9.6, SD 13.7, $n=100$ ). However, Common Minke Whales (Balaenoptera acutorostrata) were the most commonly observed species, with an average daily observation probability of $71.9 \%$. Due to their smaller pod sizes (mean 1.0, SD 0.3, $n=734$ ), they had the second highest counts (Table 1).

The overall daily probability of seeing a marine mammal (regardless of species) during any 10-minute observation period was estimated to be $88 \%$. A mean of 2.6 (SD 1.2) marine mammal species was observed per day (range 1-5 species/day). Slightly less than $10 \%$ $(n=176)$ of all individuals counted were classed as feeding, and the majority of these observations were attributed to whales (e.g., mainly Common Minke Whale lunge feeding). Less than $5 \%(n=72)$ of all individuals counted were classed as spying, and these were all attributed to seals (e.g., primarily Harp Seals).

The highest probability of observing Harp Seals occurred in June and August (i.e., a bimodal distribution), with August being the secondary peak and observations generally decreasing with time (Figure 2). The probability of observing Common Minke Whales seemed to increase with time: they had reached peak occurrence by mid-September (Figure 2). Humpback Whales (Megaptera novaeangliae) were not observed until late August, but they were observed regularly thereafter until the end of the study (Figure 2). Ringed Seals were not observed in great numbers, and their highest observation probability occurred during the first part of the study (Figure 2). 
TABLE 1. Summary of marine mammal observations between 11 July and 28 September 2012. The mean pod size (standard deviation in parentheses) is calculated as the total number of individuals divided by the number of pods observed. The range column indicates the minimum and maximum number of marine mammal pods observed during any given observation period over the course of the survey.

\begin{tabular}{|c|c|c|c|c|c|}
\hline Species $^{1}$ & $\begin{array}{l}\text { Daily mean } \\
\text { observation } \\
\text { probability }^{2}\end{array}$ & $\begin{array}{c}\text { Number of } \\
\text { pods } \\
\text { observed }\end{array}$ & $\begin{array}{c}\text { Total } \\
\text { number of } \\
\text { individuals }\end{array}$ & $\begin{array}{c}\text { Mean } \\
\text { pod size }\end{array}$ & Range \\
\hline $\begin{array}{l}\text { Common Minke Whale } \\
\text { (Pamiuligak) }\end{array}$ & 0.719 & 734 & 765 & $1.0(0.3)$ & $1-5$ \\
\hline $\begin{array}{l}\text { Harp Seal } \\
\text { (Kaigulik) }\end{array}$ & 0.205 & 100 & 960 & $9.6(13.7)$ & $1-60$ \\
\hline $\begin{array}{l}\text { Humpback Whale } \\
\text { (Apvik) }\end{array}$ & 0.151 & 56 & 58 & $1.0(0.2)$ & $1-2$ \\
\hline $\begin{array}{l}\text { Ringed Seal } \\
\text { (Natsik) }\end{array}$ & 0.069 & 27 & 28 & $1.0(0.2)$ & $1-2$ \\
\hline $\begin{array}{l}\text { Bearded Seal } \\
\text { (Utjuk) }\end{array}$ & 0.042 & 8 & 9 & $1.1(0.4)$ & $1-2$ \\
\hline $\begin{array}{l}\text { Grey Seal } \\
\text { (Apa) }\end{array}$ & 0.028 & 9 & 9 & $1.0(0.0)$ & - \\
\hline $\begin{array}{l}\text { Harbour Seal } \\
\text { (Kasigiak) }\end{array}$ & 0.019 & 7 & 9 & $1.3(0.8)$ & $1-3$ \\
\hline $\begin{array}{l}\text { Harbour Porpoise } \\
\text { (Nesâtsuk) } \\
\text { Summary }\end{array}$ & 0.003 & $\begin{array}{c}1 \\
942\end{array}$ & $\begin{array}{c}3 \\
1841\end{array}$ & $\begin{array}{c}3 \\
1.9(5.2)\end{array}$ & $\begin{array}{c}3 \\
1-60\end{array}$ \\
\hline
\end{tabular}

${ }^{1}$ Inuttitut name in the Rigolet dialect of Labrador Inuttitut shown in parentheses.

${ }^{2}$ The mean observation probability is the chance of observing a species on any given day averaged over the course of the study and is based on the daily observation probability (see Methods). The daily observation probability, which also factors in the number of observation periods when a species is not recorded, is not directly related to the number of pods or total counts. The observation probability does not sum to 1.0, since, during any given 10-minute observation period, all eight species could be observed and documented (although in practice that did not happen).

In addition to the observations reported above, a small pod of Beluga Whales (Delphinapterus leucas), known as Kilalugak by local Inuit, were observed near the community wharf and remained in the area for approximately one week in early July prior to the start of the study. Residents of the community also observed Beluga Whales later in the summer, but not during established observation periods.

\section{Discussion}

In terms of observation bias, species closest to the shore were assumed to be the easiest to observe and identify. Likewise, larger species (i.e., whales) were assumed to have higher detection rates than smaller species (i.e., seals), with the possible exception of Harp Seals, which occurred in large pods. It was also assumed that local small vessel traffic, especially speed boats, disturbed all observed species and could have affected the overall detection rates.

We made no effort to correct the number of sightings based on repeated observations, detection bias, or tolerance to disturbance. Therefore, our results should be viewed as indices of seasonal occurrence and relative abundance rather than as population counts. The daily observation probabilities (Figure 2) reduce the inflationary impacts of repeated observations, and they complement the other data (Table 1). For example, ranking the species based on the number of pods ob- served and observation probability (Table 1) produces a nearly identical rank order.

Within this context, Harp Seals and Common Minke Whales were the most commonly observed species, while Humpback Whales were the next most frequent species. At least one marine mammal species was observed each day (range 1-5), and at least one was observed in approximately $88 \%$ of the 10 -minute observation periods. These results suggest that overall detection rates were high. About $10 \%$ of all observations were classed as feeding; however, actual feeding rates could have been much higher. Events designated as feeding were often associated with Common Minke Whale lunge feeding on observable schools of Capelin (Mallotus villosus), which are easily observable because they make a distinct rippling pattern on the surface of the water.

Ringed Seals were not observed in great numbers (i.e., 28 counted), even though the adjacent area of Lake Melville is known by local aboriginal people to be a regionally important area for Ringed Seal whelping. It is possible that Ringed Seals remain resident in Lake Melville year round or that Ringed Seals dispersed from Lake Melville prior to the commencement of the study.

Local elders in North West River (a community situated on the west end of Lake Melville) report that Ringed Seals are rarely observed in Lake Melville dur- 


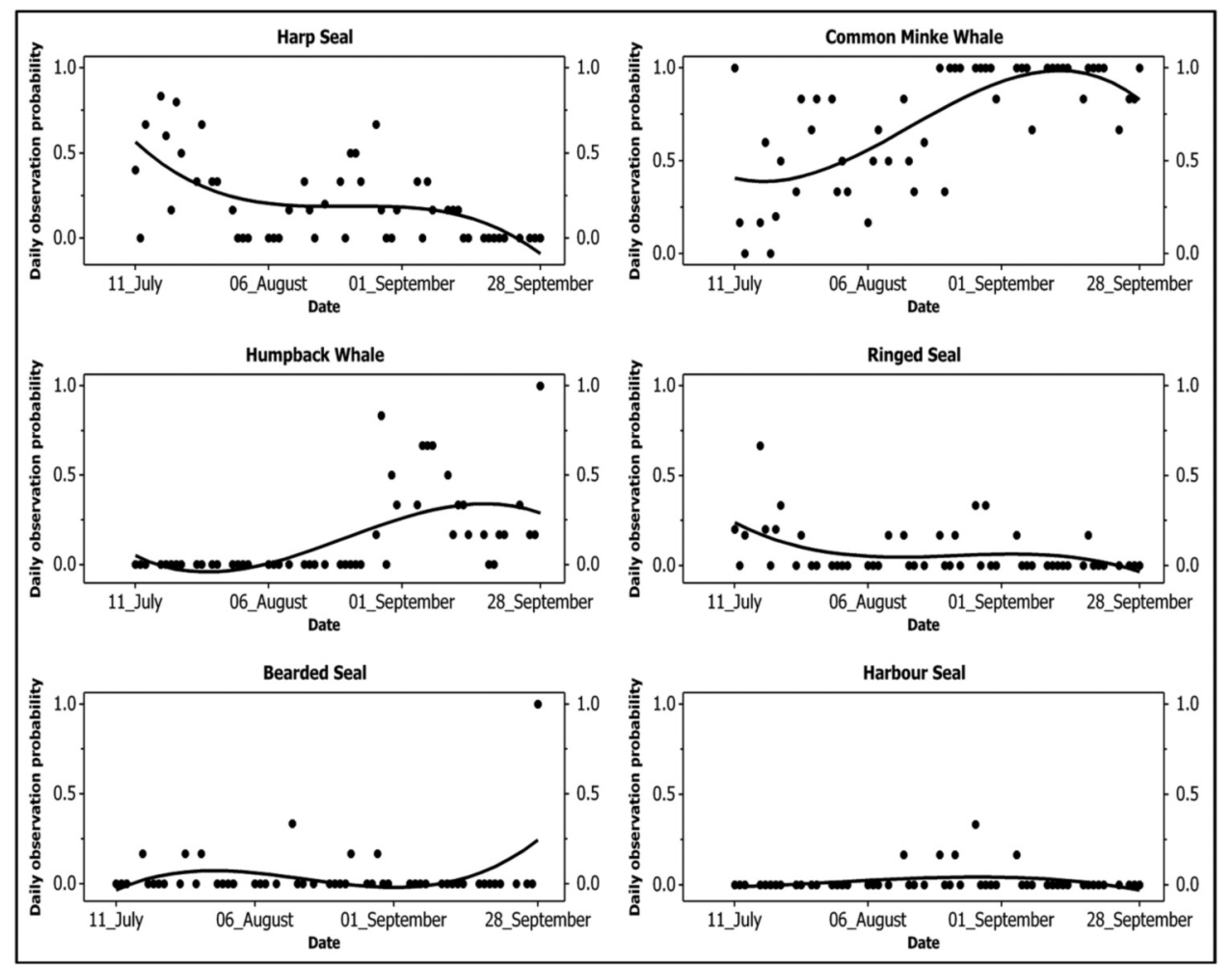

FIGURE 2. Scatter-plots of daily observation probability for Harp Seals (Pagophilus groenlandicus), Common Minke Whales (Balaenoptera acutorostrata), Humpback Whales (Megaptera novaeangliae), Ringed Seals (Pusa hispida), Bearded Seals (Erignathus barbatus), and Harbour Seals (Phoca vitulina) from 11 July to 28 September 2012, arranged by date. The daily observation probability is based on presence and absence data (a typical observation day has six observation periods of 10 minutes each) (see Methods).

ing the summer, compared with early spring, when ice is still present (B. Chaulk, personal communication). In addition, recent unpublished tracking data (B. Sjare, personal communication) suggest that Ringed Seals move in and out of Lake Melville from other areas of coastal Labrador over the course of the ice-free period. This finding is consistent with the movement dynamics of Ringed Seals observed by other researchers (e.g., Kelly et al. 2010).

Harbour Seals (Phoca vitulina) are hunted by Inuit in Groswater Bay and occasionally in Lake Melville; however, this species was rarely observed during our study, with only nine Harbour Seals counted. It may be that Harbour Seals do not frequent the area close to the Narrows for various reasons (i.e., sensitivity to disturbance, preferred feeding habitat occurs elsewhere, avoidance of humans). Likewise, Grey Seals (Halichoerus grypus) and Bearded Seals (Erignathus barbatus) were observed in low numbers, with the Harbour Porpoise (Phocoena phocoena) listed as the least frequently observed species.

In addition, a number of Beluga Whales were also observed by the study team, but not during our obser- vation periods, and are therefore not included in the overall counts. However, to support a better understanding of the overall marine mammal biodiversity, these sightings were included as anecdotal observations. It is not known if these Beluga Whales were affiliated with populations in northern Quebec, the Gulf of St. Lawrence, or elsewhere. However, because of the conservation status of those populations (the Ungava Bay population is designated endangered by the Committee on the Status of Endangered Species in Canada (COSEWIC) and the St. Lawrence estuary population is designated threatened) (COSEWIC 2004*; Hammill et al. 2004; Fisheries and Oceans Canada 2012*), we documented all Beluga Whale sightings. This information may help to delineate their distribution and population trends. In addition to the marine mammals listed here, Polar Bears (Ursus maritimus) from the Davis Strait subpopulation are also found in the Labrador region, including Groswater Bay (COSEWIC $2008^{*}$ ). None were observed during this study.

It is unclear how the study area compares with other regions of Labrador in terms of the diversity, relative abundance, and seasonal occurrence of marine mam- 
mals. Personal observation (by the lead author) and other sources (e.g., Sjare and Reddin 2002*) suggest that Common Minke Whales and many of the seal species are ubiquitous throughout coastal Labrador. Employing similar methods at other sites along the Labrador coast could provide a better understanding of regional marine mammal ecology, especially with respect to incidence, relative abundance, and diversity.

This study program was relatively cost effective to implement. It required very little in the way of equipment, logistics, or funding other than salaries for the field team. For groups looking to lower costs, a reduced version of this study program with fewer daily observations could be run by a small group of volunteers. Other possible suggestions with respect to study design might include adding a second observation post away from the local community to act as a frame of reference.

In the next decade, the Labrador region is expected to undergo significant industrial development, including but not limited to marine shipping, hydroelectricity, offshore oil exploration, and mining. One of the most imminent large-scale projects in the region is the Muskrat Falls hydroelectric project. Muskrat Falls is located $180 \mathrm{~km}$ upstream from the community of Rigolet on the Churchill River. The Government of Newfoundland and Labrador sanctioned the project in December 2012, with major construction commencing in 2013. Should this development proceed, there is the potential for the downstream transport of methylmercury from the reservoir and down-stream nutrient loss as a consequence of regulating spring run-off from the Churchill River via the Muskrat Falls dam site. As a consequence, there could be long-term impacts on the marine ecosystem, and our data could serve as an important baseline for the region.

\section{Acknowledgements}

We thank the Rigolet Inuit Community Government and the Tasiujaksoak Trust for funding this project. Thanks are extended to Eldred Allen and Bryn Wood for assisting in figure production and to Ellen Adams for reviewing the Inuttitut species names. Thanks to Thomas Jung, Martha MacDonald, Morgon Mills, Becky Sjare, John Trehune, and Jane Watson, whose review comments greatly improved the quality of this paper.

\section{Documents Cited (marked * in text)}

Committee on the Status of Endangered Wildlife in Canada (COSEWIC). 2004. COSEWIC assessment and update status report on the beluga whale Delphinapterus leucas in Canada. Committee on the Status of Endangered Wildlife in Canada. Ottawa, Ontario. ix +70 pages.

Committee on the Status of Endangered Wildlife in Canada (COSEWIC). 2008. COSEWIC assessment and update status report on the polar bear Ursus maritimus in Canada. Committee on the Status of Endangered Wildlife in Canada, Ottawa, Ontario. vii +75 pages.
Environment Canada Online. Canadian Climate Normals 1971-2000 for Cartwright weather station. Accessed April 8, 2013.

Fisheries and Oceans Canada. 2012. Recovery strategy for the Beluga (Delphinapterus leucas) St. Lawrence Estuary population in Canada. Species at Risk Act Recovery Strategy Series. Fisheries and Oceans Canada, Ottawa, Ontario. $88+x$ pages.

Meades, S. 1990. Natural regions of Newfoundland and Labrador. Protected Areas Association of Newfoundland and Labrador, St. John's, Newfoundland and Labrador.

Rao, A., L-A. Outhouse, and D. Gregory. 2009. Special marine areas of Newfoundland and Labrador: areas of interest in our marine back yard. Report prepared for Canadian Parks and Wilderness Society, Newfoundland and Labrador Chapter, St. John's, Newfoundland and Labrador.

Sjare, B., and D. Reddin. 2002. Comments on the predation of salmon by seals in the coastal waters of Newfoundland and Labrador. Pages 86-87 in Causes of Marine Mortality of Salmon in the North Pacific and North Atlantic Oceans and in the Baltic Sea. Joint Meeting on Causes of Marine Mortality of Salmon in the North Pacific and North Atlantic Oceans and in the Baltic Sea, March 14-15, 2002, Vancouver, British Columbia. Technical Report No. 4. North Pacific Anadromous Fish Commission, Vancouver, British Columbia.

\section{Literature Cited}

Andersen, J. M., Y. F. Wiersma, G. Stenson, M. O. Hammill, and A. Rosing-Asvid. 2009. Movement patterns of hooded seals (Cystophora cristata) in the Northwest Atlantic Ocean during the post-moult and pre-breeding seasons. Journal of Northwest Atlantic Fisheries Science 42: 1-11.

Arkham, S. 1984. The Basque whaling establishments in Labrador 1536-1632: a summary. Arctic 37: 515-519.

Beck, G. G., M. O. Hammill, and T. G. Smith. 1993. Seasonal variation in the diet of harp seals (Phoca groenlandica) from the Gulf of St. Lawrence and western Hudson Strait. Canadian Journal of Fisheries and Aquatic Sciences 50: $1363-1371$.

Ecoregions Working Group. 1989. Ecoclimate Regions of Canada. Ecological Land Classification series no. 23. Canadian Wildlife Service, Environment Canada.

Hammill, M. O., V. Lesage, J.-F. Gosselin, H. Bourdages, B. G. E. De March, and M. C. S. Kingsley. 2004. Evidence for a decline in northern Quebec (Nunavik) belugas. Arctic 57: 183-195.

Kelly, B. P., O. H. Badajos, M. Kunnasranta, J. R. Moran, M. Martinez-Bakker, D. Wartzok, and P. Boveng. 2010. Seasonal home ranges and fidelity to breeding sites among Ringed Seals. Polar Biology 33: 1095-109.

Kuzyk, Z. A., J. P. Stow, N. M. Burgess, S. M. Solomon, and K. J. Reimer. 2005. PCBs in sediments and the coastal food web near a local contaminant source in Saglek Bay, Labrador. Science of the Total Environment 352: 264-284.

Lopoukhine N., N. A Prout, and H. E Hirvonen. 1978. The Ecological Land Classification of Labrador: a Reconnaissance. Series 4. Environment Canada, Ottawa, Ontario.

Nettleship, D. N., and P. G. H. Evans. 1985. Distribution and status of Atlantic Alcidae. Pages 53-154 in The Atlantic Alcidae. Edited by D. N. Nettleship and T. R. Birkhead. Academic Press, London. 
Oftedal, O. T., W. D. Bowen, and D. J. Boness. 1996. Lactation performance and nutrient deposition in pups of the Harp Seal, Phoca groenlandica, on ice floes off southeast Labrador. Physiological Zoology 69: 635-657.

Sergeant, D. E., and H. D. Fisher. 1957. The smaller Cetacea of eastern Canadian waters. Journal of the Fisheries Research Board of Canada 14: 83-115.

Stenson, G. B., and B. Sjare. 1997. Seasonal distribution of harp seals, Phoca groenlandica, in the Northwest Atlantic. $\mathrm{CC}: 10$ in Theme Session on Biology and Behaviour (II)
(CC). Annual Science Conference of the International Council for the Exploration of the Sea (ICES), 1997, Baltimore, Maryland. ICES Conference and Meeting (CM) documents. International Council for the Exploration of the Sea, Copenhagen, Denmark. CM 1997/CC:10. Microfiche.

Received 3 December 2012

Accepted 21 February 2013 